\title{
Geoelectrical and Geotechnical Investigations of Subsurface Corrosivity in Ondo State Industrial Layout, Akure, Southwestern Nigeria*
}

\author{
${ }^{1}$ I. A. Adeyemo, ${ }^{1}$ O. A. Olumilola and ${ }^{2}$ M. A. Ibitomi \\ ${ }^{1}$ Federal University of Technology, Akure, Nigeria \\ ${ }^{2}$ Kogi State Polythechnic, Lokoja, Nigeria
}

Adeyemo, I. A. Olumilola, O A.and Ibitomi, M. A. (2018), "Geoelectrical and Geotechnical Investigations of Subsurface Corrosivity in Ondo State Industrial Layout, Akure, Southwestern Nigeria", Ghana Mining Journal, Vol. 18, No. 1, pp. 20 - 31.

\begin{abstract}
Fifty two vertical electrical sounding (VES) data and six subsurface soil samples were collected at Ondo State Industrial Layout, Akure, south-western Nigeria in order to determine the subsurface corrosivity. The VES results delineated 3 to 5 geoelectric layers across the area, which correspond to topsoil, weathered layer, weathered basement, weathered/fractured basement and the presumed fresh bedrock. The layer resistivity values range from 22 to $602 \mathrm{ohm}-\mathrm{m}, 7$ to $2468 \mathrm{ohm}-\mathrm{m}, 17$ to $436 \mathrm{ohm}-\mathrm{m}, 25$ to $39 \mathrm{ohm}-\mathrm{m}$ and 203 to $10023 \mathrm{ohm}-\mathrm{m}$ in the topsoil, weathered layer, weathered basement, weathered/fractured basement and the presumed fresh bedrock respectively. The iso-resistivity maps at depth slices of 1 and $2 \mathrm{~m}$ show that the northeastern, southeastern and the upper central part of the area are non-corrosive (above $350 \mathrm{ohm}-\mathrm{m}$ ) to slightly corrosive $(250-350 \mathrm{ohm}-\mathrm{m})$, while the lower central, northwestern and southwestern parts of the area are moderately $(150-250 \mathrm{ohm}-\mathrm{m})$ to strongly corrosive $(60-150 \mathrm{ohm}-\mathrm{m})$. Soil sample analysis shows liquid limit results that vary from 37.6 to 59.7 , while the plasticity limit results vary from 29.3 to 42.5 and all the plasticity index plots were below the A line indicating presence of non-plastic clay. The natural moisture content values vary from 21.4 to $35.5 \%$. The $2 \mathrm{~m}$ depth slice isoresistivity map and clay plasticity factor were synthesized using additive model to generate subsurface CRindex corrosivity model map which indicates that the northwestern, north-eastern and southern parts of the area are moderately $(0.4-0.6)$ to strongly corrosive $(0.6-0.8)$, while the upper central area and the flanks are slightly corrosive. The moderately and strongly corrosive zones correspond to the low elevation and water logged zones of the study area. The corrosivity model map was validated by the $\mathrm{pH}$ and corrosivity data.
\end{abstract}

Keywords: Geotechnical, Liquid Limit, Plastic Limit, Plasticity Index, Clay Plasticity

\section{Introduction}

Corrosion is defined as the degradation of a material or its properties due to a reaction with the environment (Owate et al., 2002) and it exists in virtually all materials but is mostly associated with metals. Effects of corrosion on engineering structures include; loss of stress, fatigue, reduced bond strength, limited ductility and reduced shear capacity (Gebremedhin et al., 2013). Soil corrosivity is caused by several soil properties such as; resistivity, $\mathrm{pH}$, redox potential, sulfides concentration, percentage clay content and moisture content (Najjaran et al., 2004 and Idornigie et al., 2006).

Few woks have been done on corrosivity; Najjaran et al., (2004) demonstrated the application of fuzzy logic in predicting deterioration of cast/ductile iron water mains using soil properties. This approach utilized a model consisting of a series of 'IF THEN' rules to determine soil corrosivity potential based on soil properties such as resistivity, $\mathrm{pH}$, redox potential, sulfides, percentage clay content and moisture content. Different models relating corrosivity potential and different soil properties had been generated. Idornigie et al., (2006) carried out 1063 Vertical electrical sounding (VES) at Akungba-Akoko, Ondo State and environs in order to determine subsoil corrosivity. The work classified the subsoil into four corrosivity zones; very strongly corrosive (less than 10 ohm-m), moderately corrosive (10 - 60 ohm-m), slightly corrosive (60 - $180 \mathrm{ohm}-\mathrm{m})$ and non-corrosive (180 ohm-m and above). Oyedele et al., (2012) combined electrical resistivity tomography and hydro-chemical analysis in assessing coastal soil corrosivity at Lekki, Lagos, Nigeria. The subsurface in the area were classified into four corrosive layers; Non-corrosive (greater than 100 ohm-m), mildly corrosive (50 - 100 ohm-m), moderately corrosive (20 - $50 \mathrm{ohm}-\mathrm{m})$, corrosive (7 - 20) and very corrosive (less than 7 ohm-m). Gebremedhin et al., (2013) used AAS-UV spectrophotometer-generated hydro-geochemical data obtained from surface water, hand dug wells and boreholes in Mekelle city, Ethiopia. Water from the three sources gave Larson Index (LI) above the 0.5 threshold which were considered indicative of aggressive corrosivity. Bayowa and Olayiwola (2015) adopted electrical resistivity method in evaluating the subsurface corrosivity within the campus of Ladoke Akintola University, Ogbomoso, Nigeria. It was concluded that layers with resistivity values of $200 \mathrm{ohm}-\mathrm{m}$ and above, 
100 - 200 ohm-m and less than 100 ohm-m could be classified as non-corrosive, moderately corrosive and highly corrosive respectively. Abdullahi et al., (2016) acquired 10 VES data at Convocation Square, Kaduna State University, Kaduna Northwestern Nigeria in order to investigate the corrosivity of the subsurface soil. The subsurface were classified into three corrosivity layers; corrosive (80 - 150 ohm-m), slightly corrosive (150 - 200 ohm-m) and noncorrosive (above $200 \mathrm{ohm}-\mathrm{m}$ ).

This study attempts to combine the effect of moisture and presence of water holding lithology like clay on subsurface corrosivity.

\subsection{The Study Area}

The study area is Ondo State Industrial Estate, Akure, Southwestern Nigeria which lies between longitude 803800 and $806400 \mathrm{~m}$ (Eastings), and latitude 738600 and $740600 \mathrm{~m}$ (Northings) based on Universal Traverse Mercatum System (WGS 84 ) and the area extent is about $2.8 \mathrm{~km}^{2}$ (Figs. 1, 2 and 3). The study area is characterized by wet (April to October) and dry (November to March) seasons and mean annual rainfall range between 1000 and $1500 \mathrm{~mm}$. The vegetation of the area is of tropical rain forest type which is characterized by thick forest. The annual mean temperature ranges from 21.9 to $30.4{ }^{0} \mathrm{C}$, while humidity is relatively high during the wet season and low during the dry season with values ranging annually from 39.1 to 98.2\% (Adeyemo et. al., 2017). The area is underlain by Precambrian rock typical of the Basement Complex of Nigeria (Fig. 2). The main rock type in the area is charnockite which occurs as outcrops, residual hills and boulders in some places, and they vary in texture from fine to coarse grained structural characteristics (Rahaman, 1988 and Owoyemi, 1996).

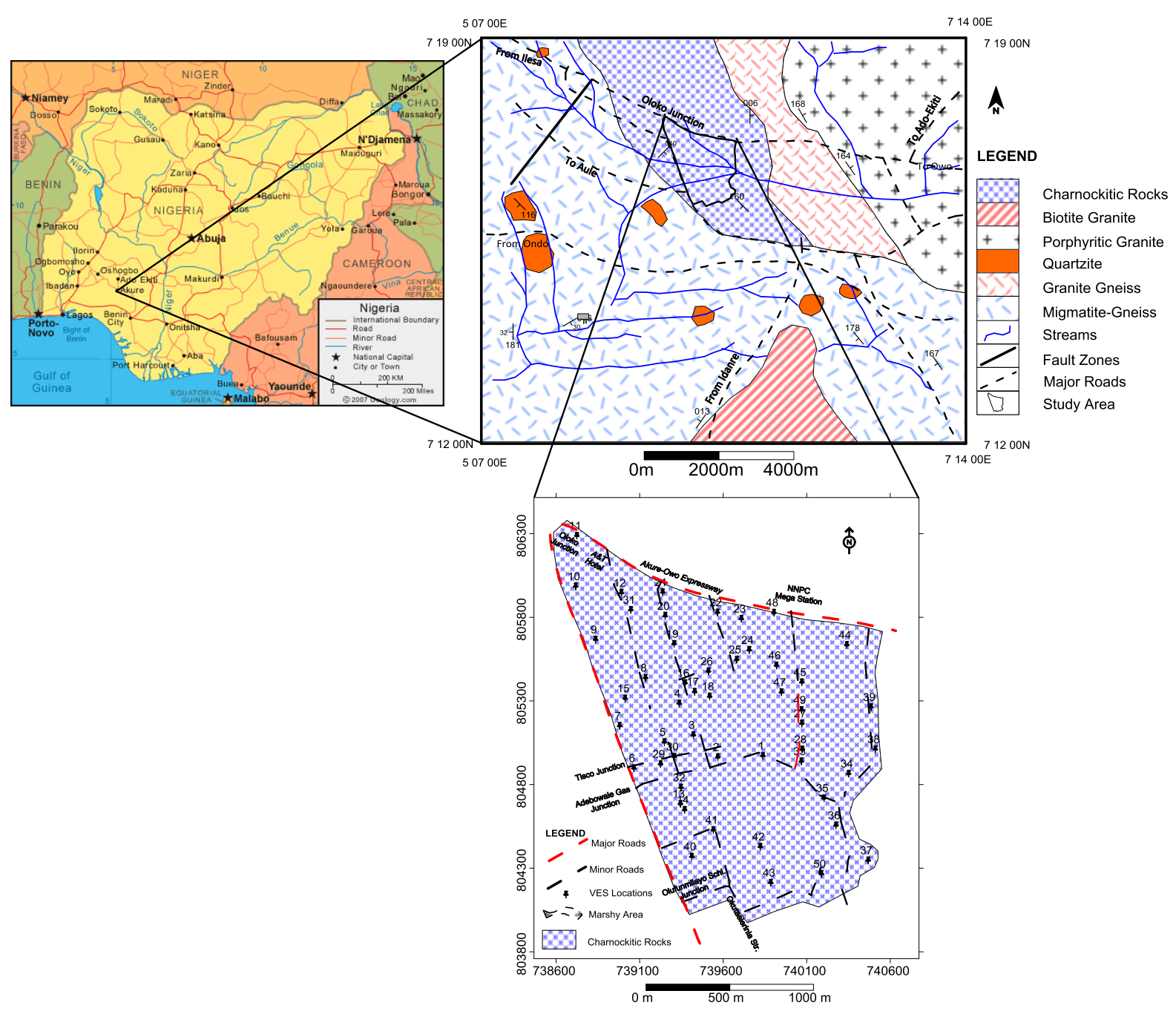

Fig. 1 (Left); Administrative Map of Nigeria, (Upper); Simplified Geological Map of Akure (Modified after Owoyemi, 1996) and (Lower); Geological Map of the Study Area 


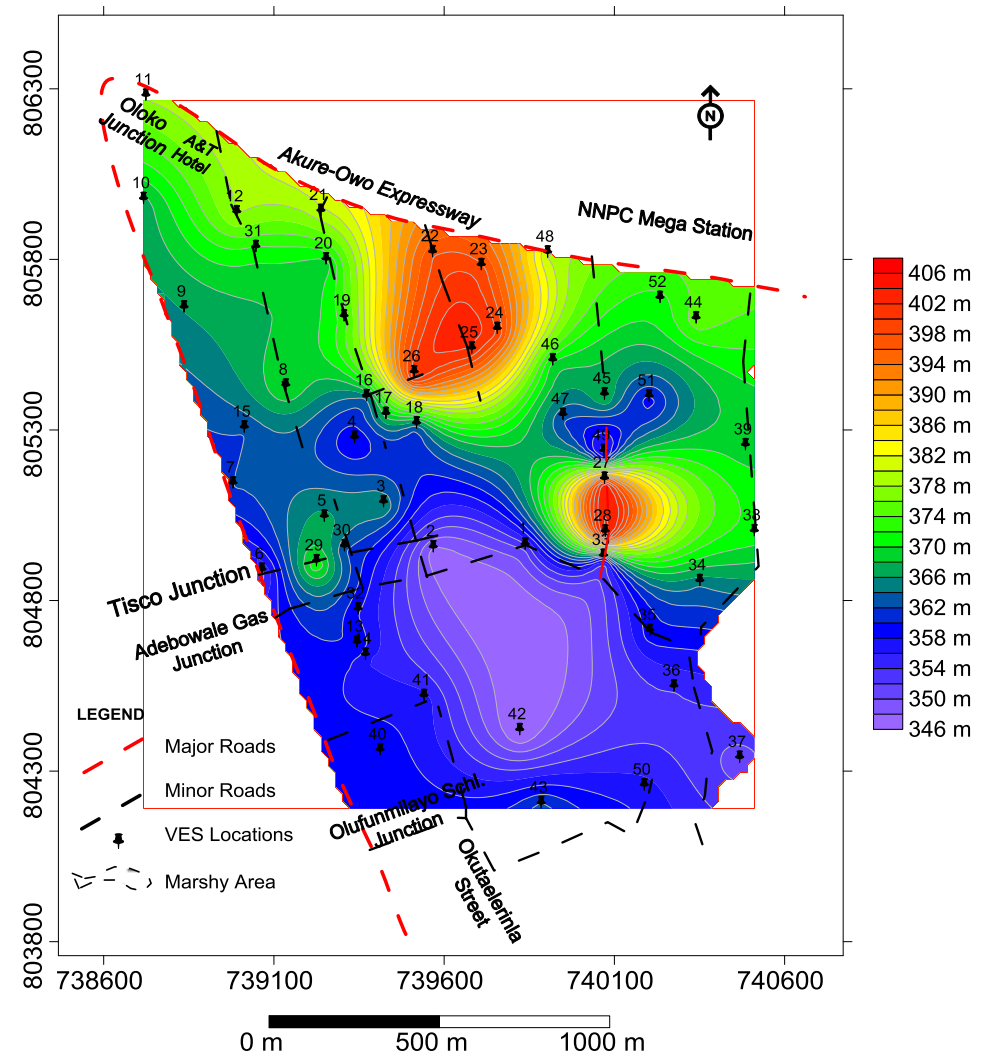

Fig. 2: Elevation Map of the Study Area

\section{Resources and Methods Used}

\subsection{Data Acquisition and Interpretation}

This study combined geoelectric sounding and geotechnical approach in investigating subsurface corrosivity at Akure Industrial estate, Akure Ondo State. The vertical electrical sounding (VES) survey utilized Schlumberger electrode configuration (Zohdy, 1965 and Koefoed, 1979). The half-current electrode spread was varied from of 1 to $150 \mathrm{~m}$ and a total of 52 VES was acquired across the study area (Fig. 3). The field data was interpreted using the conventional partial curve matching techniques (Zohdy, 1965 and Koefoed, 1979) and the resulting geoelectric parameters were further refined using Resist Version 1.0 software (Vander Velpen, 2005). Subsurface soil samples were collected at constant depth of $2 \mathrm{~m}$ across six (6) selected locations. The samples were prepared and used to determine the Liquid Limit (LL), Plastic Limit (PL) and Plsticity Index (PI). The PI value assisted in determining the clayey nature and clay type encountered in the area. The results of both geolectric sounding and consistency test were synthesized using an additive model developed by Chachadi (2005) and adopted by Adeyemo et al., (2017) to generate the final corrosivity model map.
The corrosivity model map was subsequently subjected to validation using conductivity and $\mathrm{pH}$ values obtained from water sample.

\section{Results and Discussion}

The results (Table 1) of the fifty-two (52) VES data acquire across the study area delineated nine (9) different curve types; A, H, HA, HKH, K, KAH, $\mathrm{KH}, \mathrm{KQH}$ and $\mathrm{QH}$. The most predominant curve type in the study area is the $\mathrm{KH}$ which account for $59.6 \%$. HA, $\mathrm{H}$ and $\mathrm{A}$ and curve types accounts for $38 \%, 21 \%$ and $5.8 \%$ respectively while HKH, $\mathrm{KAH}, \mathrm{KQH}$ and QH account for $1.9 \%$ each. The VES results also delineated three (3) to five (5) geoelectric layers across the area which corresponds to topsoil, weathered layer, weathered basement, weathered/fractured basement and the presumed fresh bedrock. The layer resistivity values range from 22 - 602 ohm-m, 7 - 2468 ohmm, 17 - 436 ohm-m, 25 - 39 ohm-m and 203 10023 ohm-m in the topsoil, weathered layer, weathered basement, weathered/fractured basement and the presumed fresh bedrock respectively, while layer thickness varies respectively from $0.5-7.4 \mathrm{~m}$, $1.1-21.7 \mathrm{~m}, 1.7-44.8 \mathrm{~m}$ and $12.5-55.9 \mathrm{~m}$ in the topsoil, weathered layer, weathered basement and 


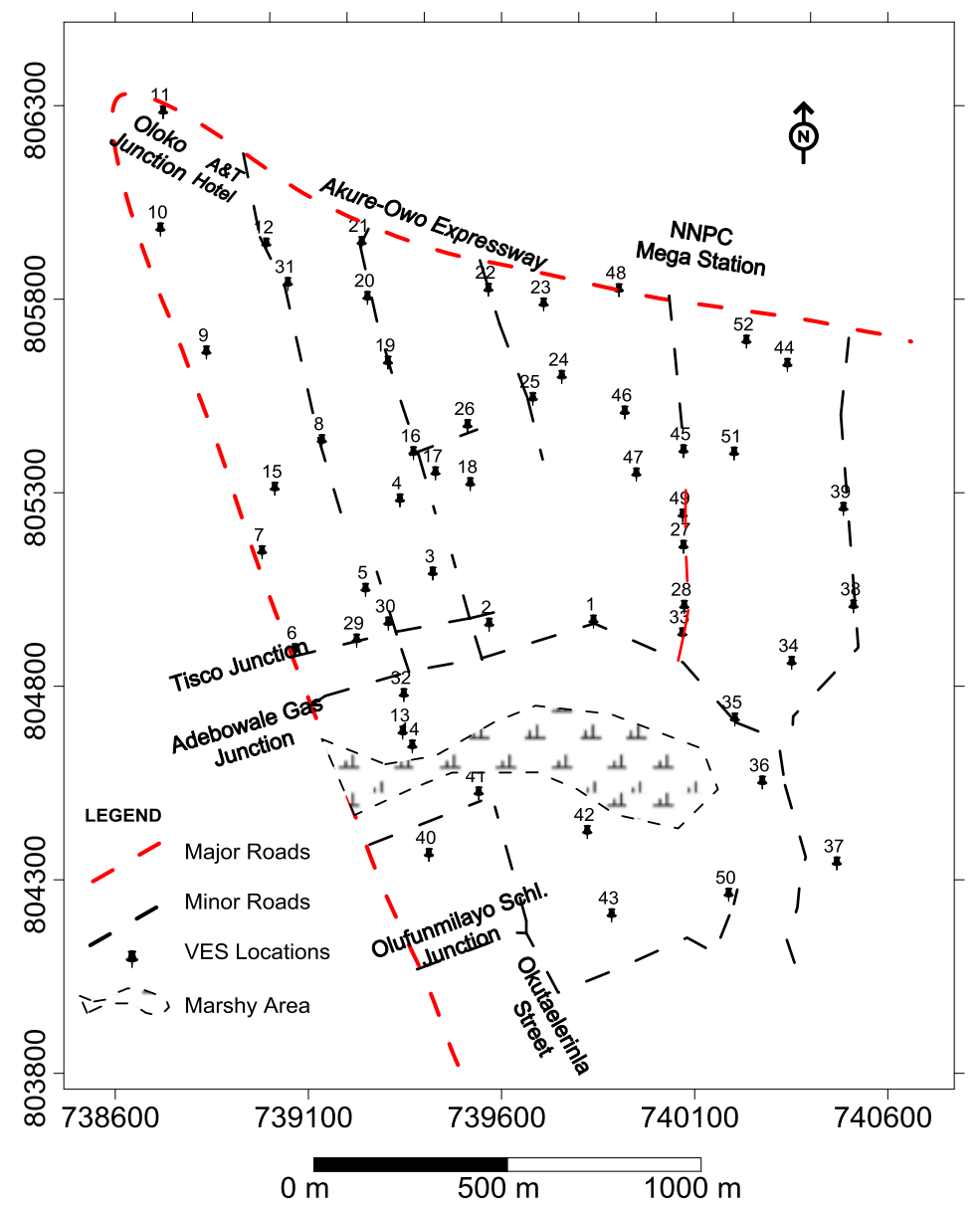

Fig. 3 Base Map of the Study Area showing VES Locations

weathered/fractured basement. The VES results were also presented as resistivity depth slice maps at 1, 2 and $3 \mathrm{~m}$ (Figs. 4 - 6).

\subsection{Depth Slice Maps}

The iso-resistivity map at depth slice of $1 \mathrm{~m}$ (Fig. 4) indicates that the northeastern, southeastern and a segment of the southwestern part of the area is non-corrosive (above $350 \mathrm{ohm}-\mathrm{m}$ ) to slightly corrosive (250 - 350 ohm-m), while the central, northwestern and southwestern part of the area are mildly (150 - $250 \mathrm{ohm}-\mathrm{m})$ to strongly corrosive (60 - $150 \mathrm{ohm}-\mathrm{m})$. The $2 \mathrm{~m}$ depth slice iso-resistivity map (Fig. 5) look similar to $1 \mathrm{~m}$ depth slice isoresistivity map. It shows that the northeastern, southeastern and the upper central part of the area are non-corrosive (above $350 \mathrm{ohm}-\mathrm{m}$ ) to slightly corrosive (250 - 350 ohm-m), while the lower central, northwestern and southwestern parts of the area are moderately $(150-250 \mathrm{ohm}-\mathrm{m})$ to strongly corrosive (60 - $150 \mathrm{ohm}-\mathrm{m})$. The iso-resistivity map at depth slice of $3 \mathrm{~m}$ (Fig. 6) also shows a similar pattern to the first two depth slice maps. The map (Fig. 6) indicates that the upper central, eastern and a portion of southwestern parts of the area are non-corrosive (above $350 \mathrm{ohm}-\mathrm{m}$ ) to slightly corrosive $(250-350 \mathrm{ohm}-\mathrm{m})$, while the north-western and central southern parts of the area are moderately (150 - $250 \mathrm{ohm}-\mathrm{m})$, to strongly corrosive $(60-150 \mathrm{ohm}-\mathrm{m})$ and very strongly corrosive (0 - 60 ohm-m).

\subsection{Natural Moisture Content and Consistency Limit Tests}

Soil analysis results in (Figs. 7(a-f) and Table 2) from all the six (6) samples collected for the consistency limit test shows that liquid limit results vary from 37.6 to 59.7 , while the plasticity limit results vary from 29.3 to 42.5 and all the plasticity index plots were all below the A line indicating presence of non-plastic clay such as chlorite, halloysites and kaolinite. The natural moisture content results (Table 2) vary from 21.4 to $35.5 \%$. This suggests that the low resistive nature of some part of the area indicating corrosivity are as a result of their high moisture contents and it is also believed that the non-plastic clayey nature of the subsurface will enhance fluid and ions movement which in turn will contribute to their corrosivity. In view of the presence of non-plastic clay such as chlorite, halloysites and kaolinite in the area subsurface plasticity index was also considered in the generation of corrosivity model map of the study area. 
Table 1: Vertical Electrical Sounding Results

\begin{tabular}{|c|c|c|c|c|}
\hline $\begin{array}{l}\text { VES } \\
\text { No } \\
\end{array}$ & $\begin{array}{l}\text { No of } \\
\text { Layers }\end{array}$ & $\begin{array}{c}\text { Resistivity (Ohm-m) } \\
\rho_{1 /} \rho_{2 /} \rho_{3} \ldots . \rho_{\mathrm{n}-1 /} \rho_{\mathrm{n}}\end{array}$ & $\begin{array}{l}\text { Thicknesses (m) } \\
\mathrm{h}_{1 /} \mathrm{h}_{2 /} \mathrm{h}_{3 \ldots \ldots} \mathrm{h}_{\mathrm{n}-1 /} \mathrm{h}_{\mathrm{n}}\end{array}$ & Curve Type \\
\hline 1 & 4 & $22 / 17 / 177 / 1666$ & $1 / 3.9 / 1.7$ & $\mathrm{HA}$ \\
\hline 2 & 4 & $132 / 197 / 46 / 308$ & $0.7 / 2.1 / 20.3$ & $\mathrm{KH}$ \\
\hline 3 & 4 & $36 / 199 / 70 / 1398$ & $0.6 / 2.6 / 17.8$ & $\mathrm{KH}$ \\
\hline 4 & 4 & $110 / 423 / 57 / 1625$ & $0.8 / 8.0 / 26.4$ & $\mathrm{KH}$ \\
\hline 5 & 4 & $70 / 140 / 65 / 543$ & $0.9 / 4.4 / 12.0$ & $\mathrm{KH}$ \\
\hline 6 & 4 & $94 / 242 / 18 / 12167$ & $0.5 / 3.4 / 19.6$ & $\mathrm{KH}$ \\
\hline 7 & 5 & $58 / 167 / 127 / 39 / 175$ & $1.4 / 7.7 / 19.4 / 12.5$ & $\mathrm{KQH}$ \\
\hline 8 & 4 & $108 / 131 / 64 / 271$ & $0.7 / 6.4 / 22.0$ & $\mathrm{KH}$ \\
\hline 9 & 4 & $43 / 54 / 24 / 1438$ & $1.0 / 4.1 / 6.7$ & $\mathrm{KH}$ \\
\hline 10 & 3 & $30 / 64 / 203$ & $0.9 / 3.3$ & $\mathrm{~A}$ \\
\hline 11 & 4 & $38 / 30 / 53 / 2575$ & $0.9 / 4.4 / 33.2$ & HA \\
\hline 12 & 4 & $110 / 166 / 110 / 2228$ & $1.0 / 6.1 / 16.6$ & KH \\
\hline 13 & 4 & $391 / 1000 / 143 / 3251$ & $0.8 / 3.3 / 24.2$ & KH \\
\hline 14 & 4 & $383 / 1387 / 68 / 1368$ & $0.6 / 2.6 / 39.9$ & $\mathrm{KH}$ \\
\hline 15 & 4 & $167 / 618 / 62 / 1838$ & $0.9 / 6.0 / 31.3$ & $\mathrm{KH}$ \\
\hline 16 & 4 & $90 / 297 / 33 / 1214$ & $0.8 / 4.9 / 17.8$ & $\mathrm{KH}$ \\
\hline 17 & 4 & $85 / 309 / 21 / 539$ & $0.9 / 3.8 / 20.1$ & $\mathrm{KH}$ \\
\hline 18 & 4 & $251 / 367 / 45 / 555$ & $1.5 / 2.8 / 21.2$ & $\mathrm{KH}$ \\
\hline 19 & 3 & $279 / 49 / 2094$ & $3.1 / 21.7$ & $\mathrm{H}$ \\
\hline 20 & 4 & $72 / 290 / 20 / 1613$ & $0.6 / 3.6 / 16.8$ & $\mathrm{KH}$ \\
\hline 21 & 3 & $40 / 510 / 229$ & $0.9 / 6.6$ & $\mathrm{~K}$ \\
\hline 22 & 4 & $124 / 503 / 92 / 2190$ & $0.8 / 3.1 / 47.4$ & $\mathrm{KH}$ \\
\hline 23 & 4 & $602 / 213 / 158 / 630$ & $0.9 / 5.3 / 28.3$ & $\mathrm{QH}$ \\
\hline 24 & 5 & $261 / 363 / 251 / 25 / 496$ & $0.8 / 2.2 / 11.6 / 55.9$ & $\mathrm{KAH}$ \\
\hline 25 & 3 & $40 / 64 / 204$ & $2.8 / 20.7$ & $\mathrm{~A}$ \\
\hline 26 & 4 & $159 / 316 / 134 / 759$ & $0.9 / 3.0 / 23.6$ & $\mathrm{KH}$ \\
\hline 27 & 3 & $100 / 22 / 1985$ & $1.4 / 6.9$ & $\mathrm{H}$ \\
\hline 28 & 3 & $509 / 34 / 835$ & $2.7 / 11.9$ & $\mathrm{H}$ \\
\hline 29 & 4 & $80 / 280 / 90 / 228$ & $1.0 / 7.7 / 23.4$ & $\mathrm{KH}$ \\
\hline 30 & 4 & $66 / 242 / 82 / 473$ & $0.9 / 9.7 / 24.6$ & KH \\
\hline 31 & 3 & $204 / 65 / 518$ & $3.9 / 21.2$ & $\mathrm{H}$ \\
\hline 32 & 4 & $217 / 318 / 107 / 256$ & $1.1 / 10.4 / 32.6$ & $\mathrm{KH}$ \\
\hline 33 & 3 & $231 / 194 / 274$ & $3.9 / 12.9$ & $\mathrm{H}$ \\
\hline 34 & 4 & $126 / 984 / 257 / 10023$ & $0.7 / 4.3 / 6.9$ & $\mathrm{KH}$ \\
\hline 35 & 4 & $109 / 136 / 62 / 7495$ & $0.9 / 3.5 / 28.9$ & $\mathrm{KH}$ \\
\hline 36 & 3 & $249 / 989 / 11130$ & $3.0 / 1.1$ & $\mathrm{~A}$ \\
\hline 37 & 3 & $200 / 40 / 460$ & $3.7 / 11.4$ & $\mathrm{H}$ \\
\hline 38 & 3 & $428 / 135 / 7382$ & $0.8 / 4.7$ & $\mathrm{H}$ \\
\hline 39 & 4 & $164 / 560 / 299 / 7318$ & $0.7 / 4.5 / 13.0$ & $\mathrm{KH}$ \\
\hline 40 & 4 & $71 / 255 / 17 / 517$ & $1.4 / 3.5 / 23.9$ & $\mathrm{KH}$ \\
\hline 41 & 3 & $146 / 7 / 484$ & $1.8 / 7.8$ & $\mathrm{H}$ \\
\hline 42 & 5 & $298 / 19 / 107 / 30 / 300$ & $1.4 / 4.7 / 17.9 / 14.9$ & $\mathrm{HKH}$ \\
\hline 43 & 4 & $117 / 253 / 25 / 8606$ & $0.6 / 1.1 / 2.2$ & $\mathrm{KH}$ \\
\hline 44 & 3 & $241 / 177 / 1442$ & $2.3 / 10.1$ & $\mathrm{H}$ \\
\hline 45 & 4 & $156 / 333 / 130 / 248$ & $0.8 / 2.7 / 12.1$ & KH \\
\hline 46 & 4 & $126 / 465 / 81 / 513$ & $0.8 / 2.8 / 25.3$ & $\mathrm{KH}$ \\
\hline 47 & 4 & $257 / 559 / 35 / 2441$ & $0.9 / 2.6 / 18.6$ & KH \\
\hline 48 & 3 & $590 / 81 / 323$ & $7.4 / 36.4$ & $\mathrm{H}$ \\
\hline 49 & 3 & $270 / 24 / 1202$ & $1.0 / 7.6$ & $\mathrm{H}$ \\
\hline 50 & 4 & $381 / 2468 / 436 / 1820$ & $1.2 / 16.4 / 44.8$ & $\mathrm{KH}$ \\
\hline 51 & 4 & $100 / 274 / 79 / 2459$ & $0.8 / 2.8 / 16.0$ & $\mathrm{KH}$ \\
\hline 52 & 4 & 70/93/17/791 & $0.9 / 1.9 / 2.1$ & $\mathrm{KH}$ \\
\hline
\end{tabular}




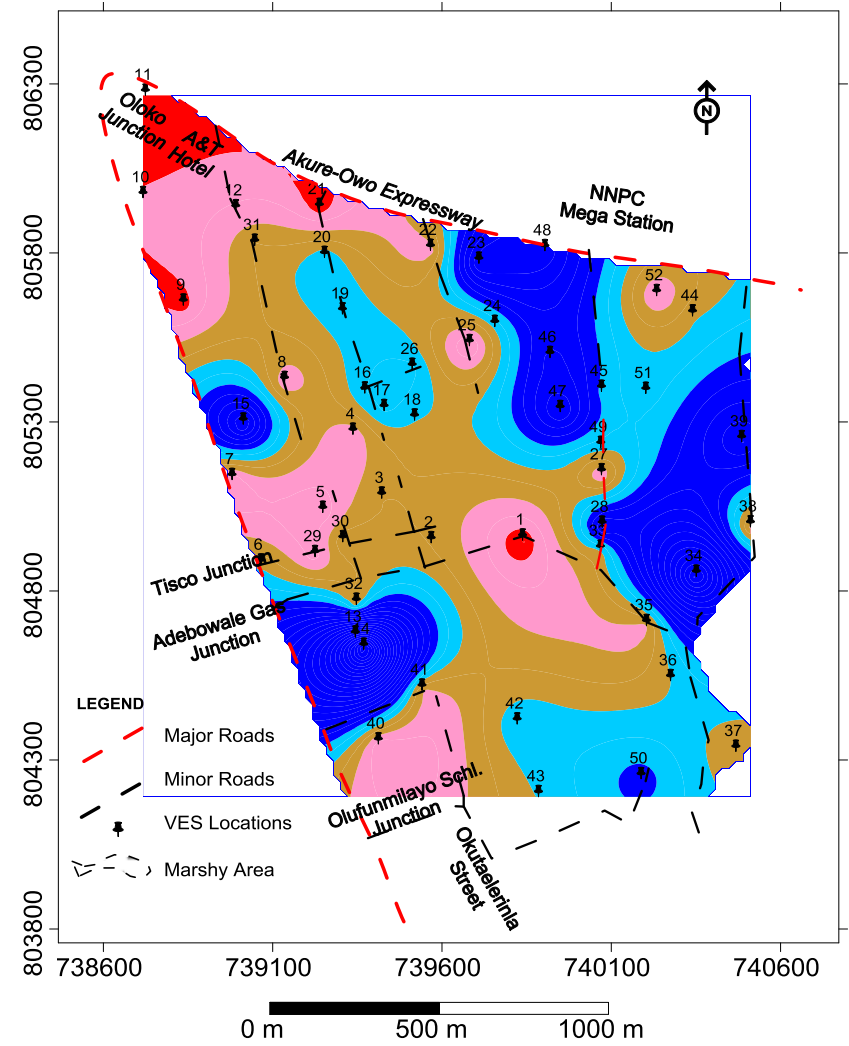

1350 ohm-m

1250 ohm-m

1150 ohm-m

1050 ohm-m

950 ohm-m

850 ohm-m

750 ohm-m

650 ohm-m

550 ohm-m

450 ohm-m

350 ohm-m

250 ohm-m

150 ohm-m

60 ohm-m

0 ohm-m

Fig. 4 Resistivity Depth Slice at 1 m

Non Corrossive Zone Slightly Corrossive Zone Moderately Corrossive Zone

Strongly Corrossive Zone

Very Strongly Corrossive Zones

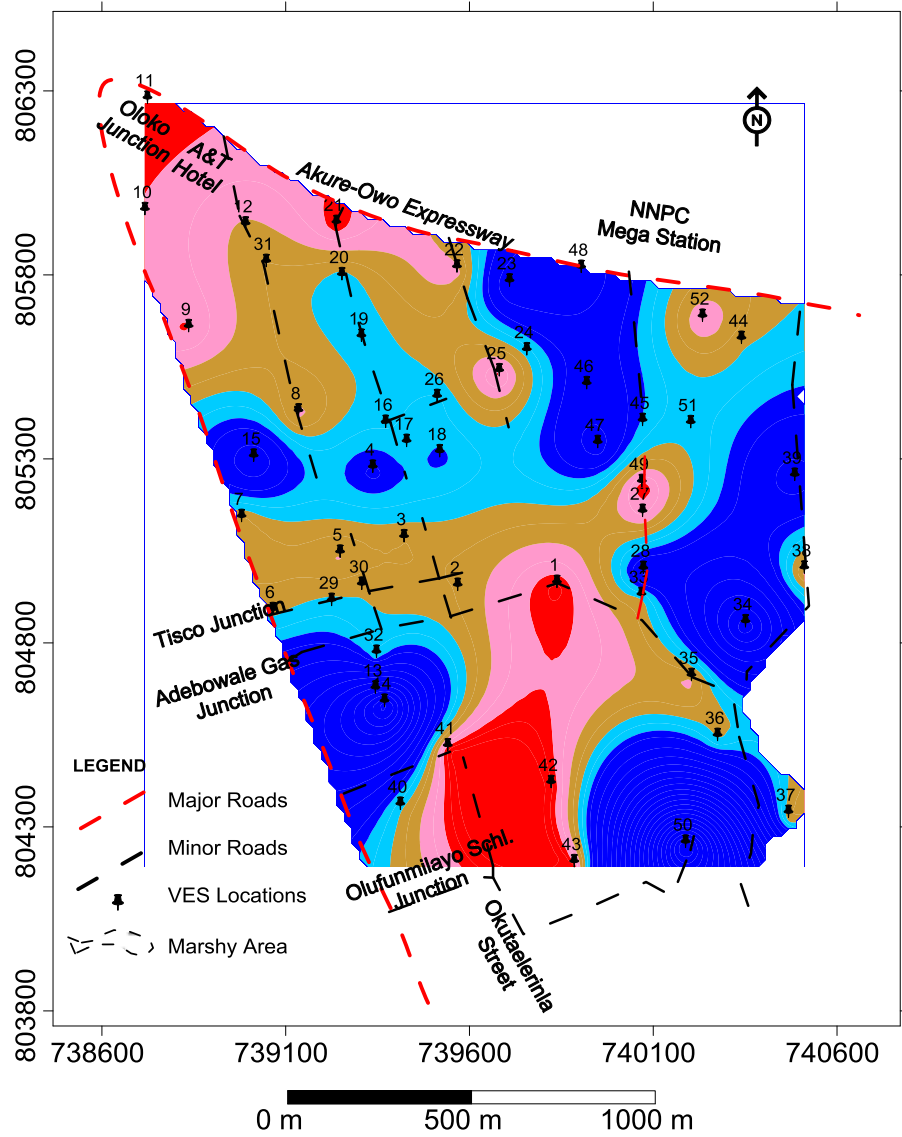

2300 ohm-m

$2100 \mathrm{ohm}-\mathrm{m}$

1900 ohm-m

1700 ohm-m

1500 ohm-m

$1300 \mathrm{ohm}-\mathrm{m}$

1100 ohm-m

900 ohm-m

700 ohm-m

500 ohm-m

350 ohm-m

250 ohm-m

150 ohm-m

60 ohm-m

0 ohm-m

Non Corrossive Zone

Slightly Corrossive Zone

Moderately Corrossive Zone

Strongly Corrossive Zone

Very Strongly Corrossive Zones

Fig. 5 Resistivity Depth Slice at 2 m 


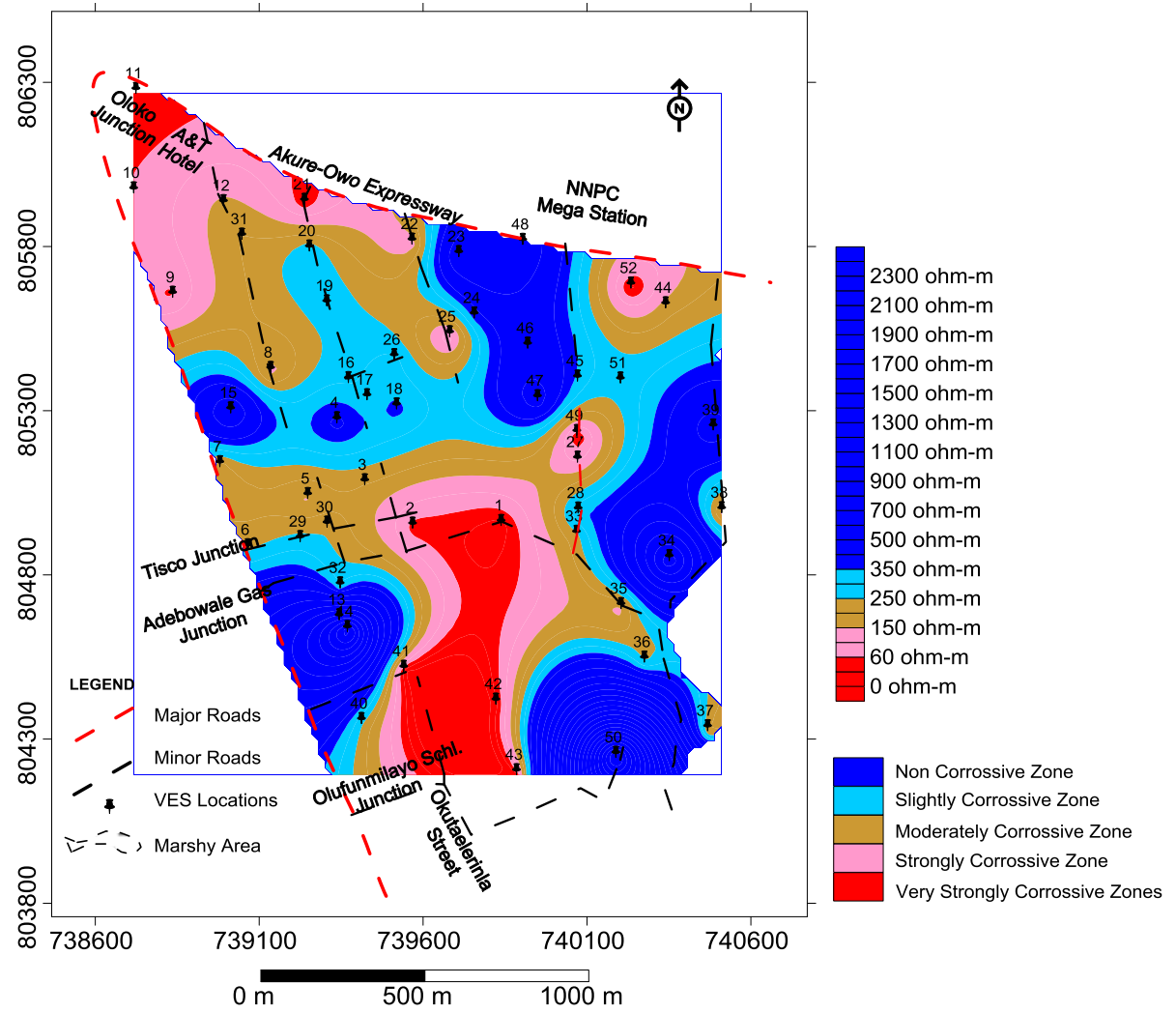

Fig. 6 Resistivity Depth Slice at 3 m

\subsection{Corrosivity Model Map}

The depth slice isoresistivity of $2 \mathrm{~m}$ and clay plasticity factor were synthesized using additive model (Chachadi, 2005 and Adeyemo et al., 2017) to generate subsurface corrosivity model map and the mathematical relationship for the CR-index value was given in equation 1 . The depth slice isoresistivity of $2 \mathrm{~m}$ was considered the most appropriate because most metallic utilities (storage tanks, pipes and others) were buried around $2 \mathrm{~m}$ depth and also the soil samples were taken from the same depth of $2 \mathrm{~m}$. The two factors; clay plasticity and subsurface resistivity were assigned weight according to their perceived contribution to corrosivity (Table 3) and each factor were given different ratings based on their increasing values (Tables 4 and 5).

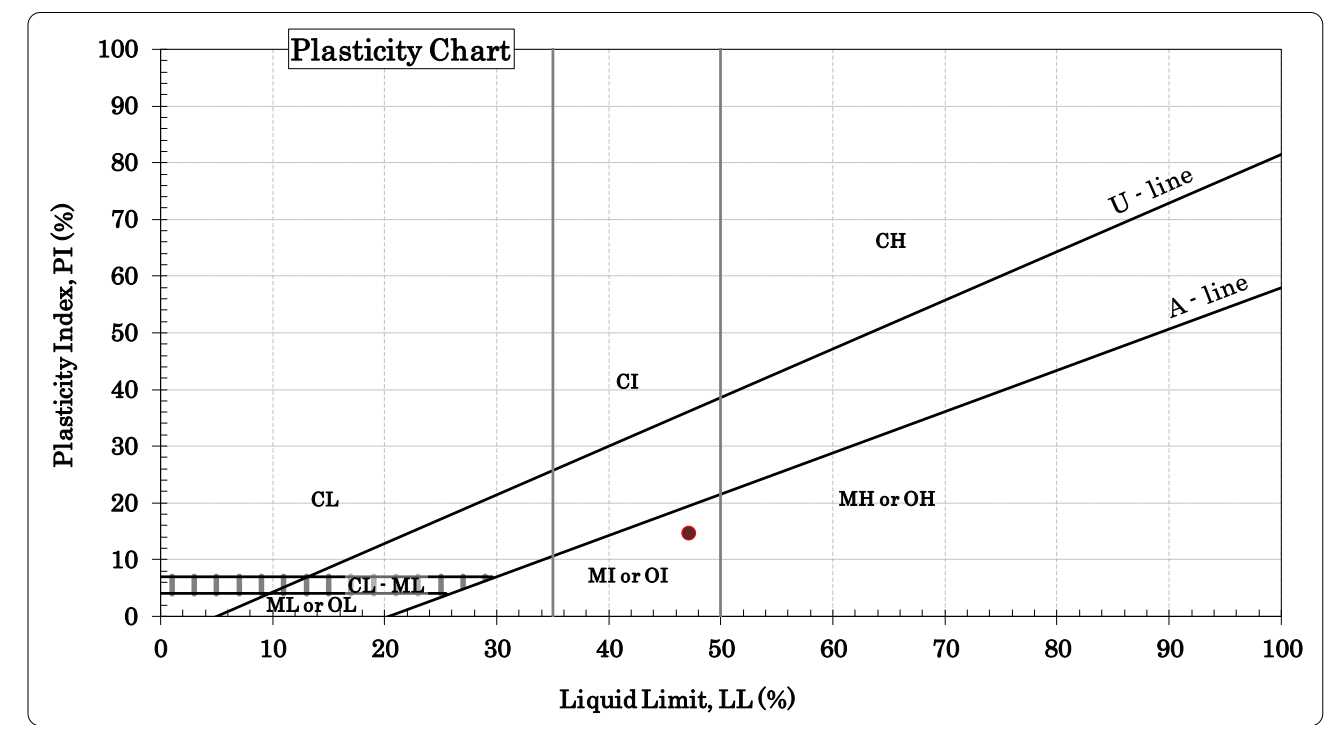

Fig. 7a Plasticity Chart of Sample A 


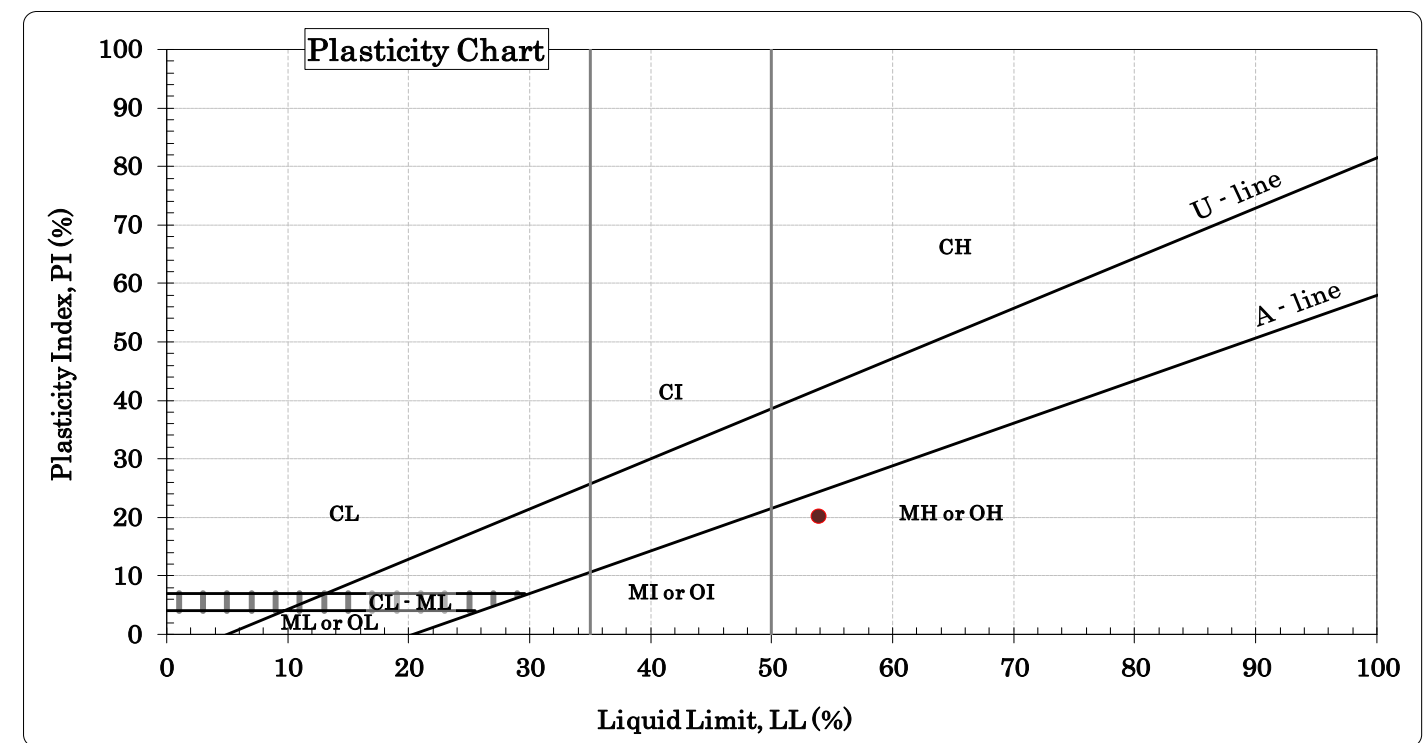

Fig. 7b Plasticity Chart of Sample B

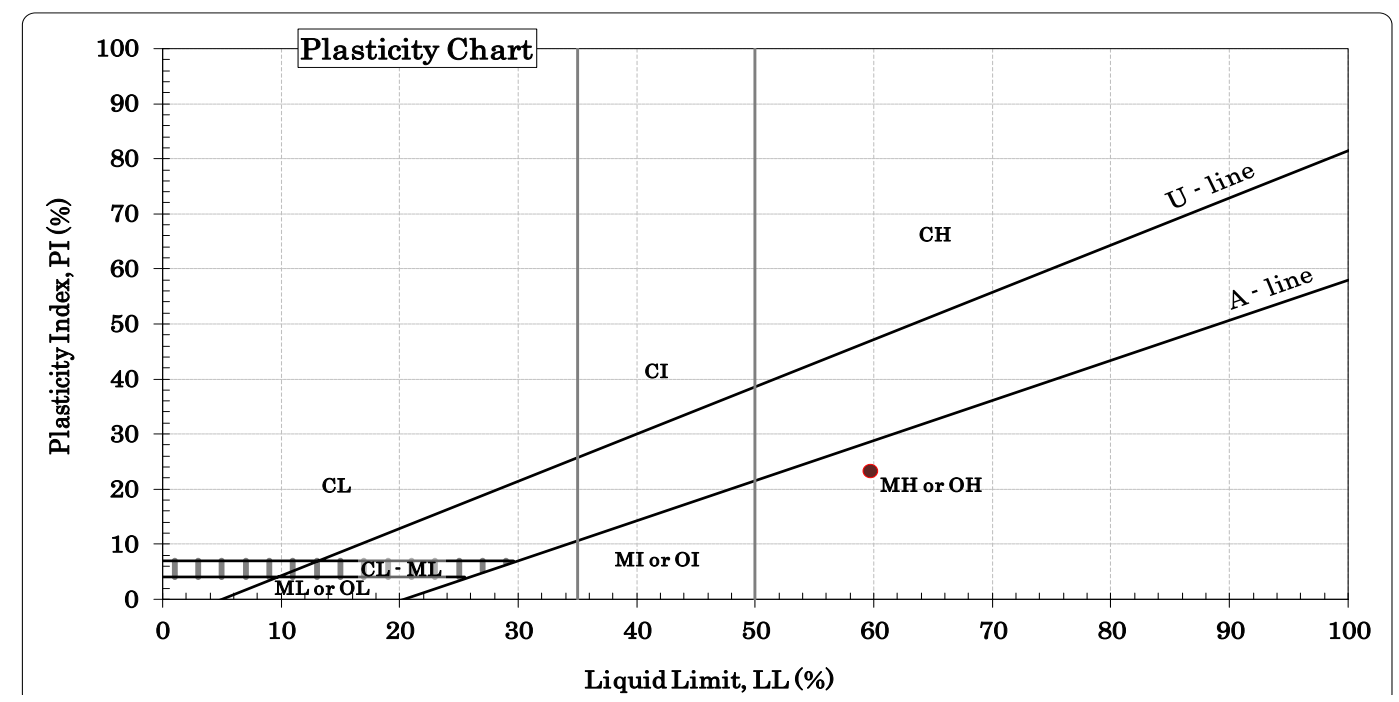

Fig. 7c Plasticity Chart of Sample C

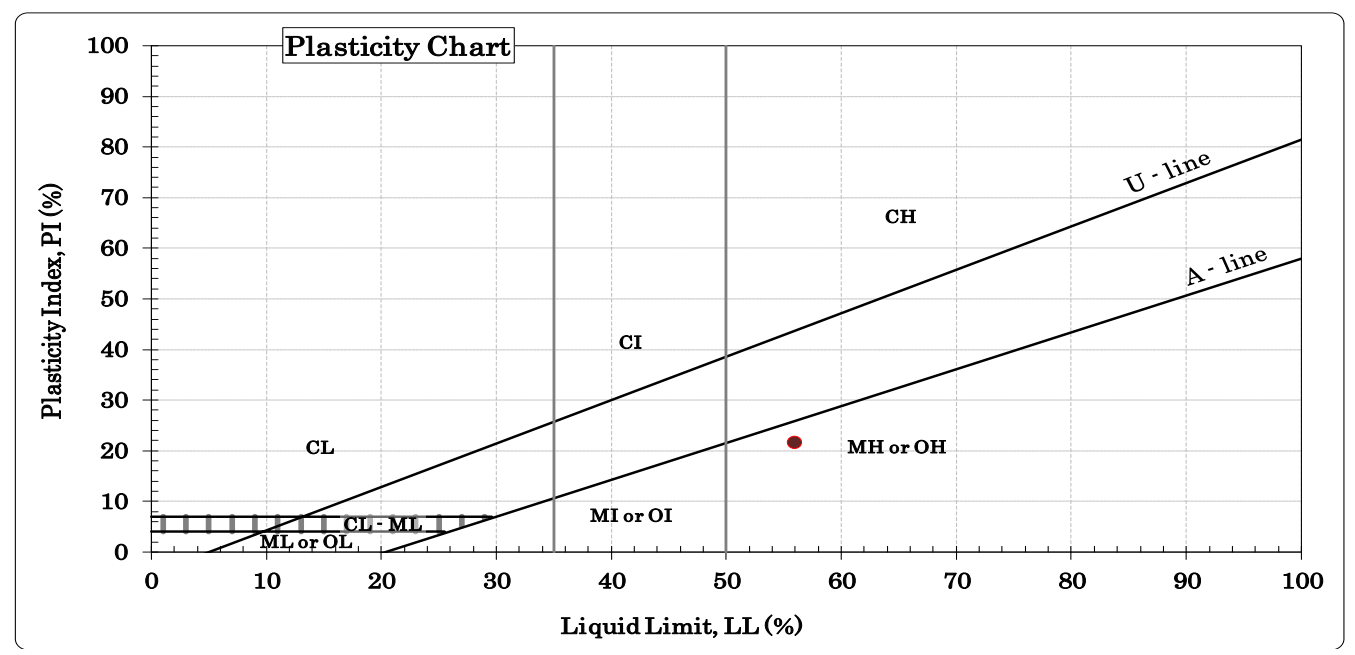

Fig. 7d Plasticity Chart of Sample D 


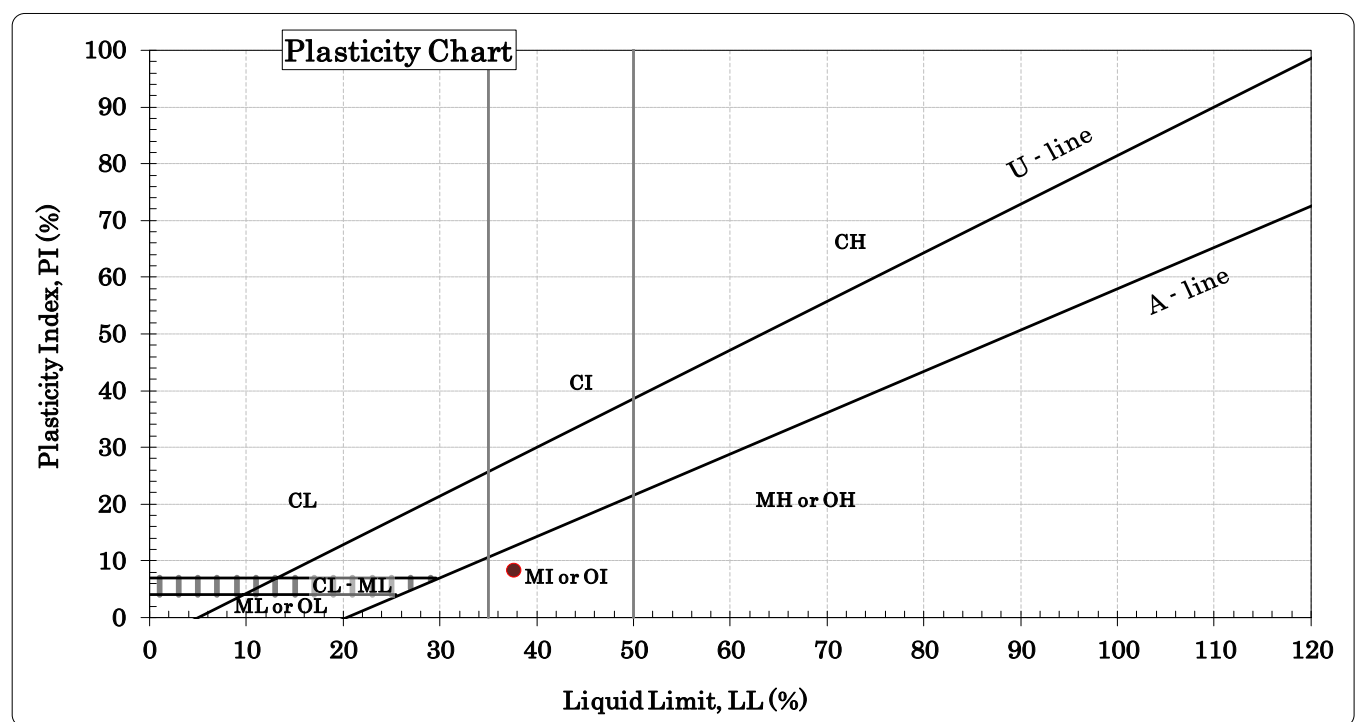

Fig. 7e Plasticity Chart of Sample E

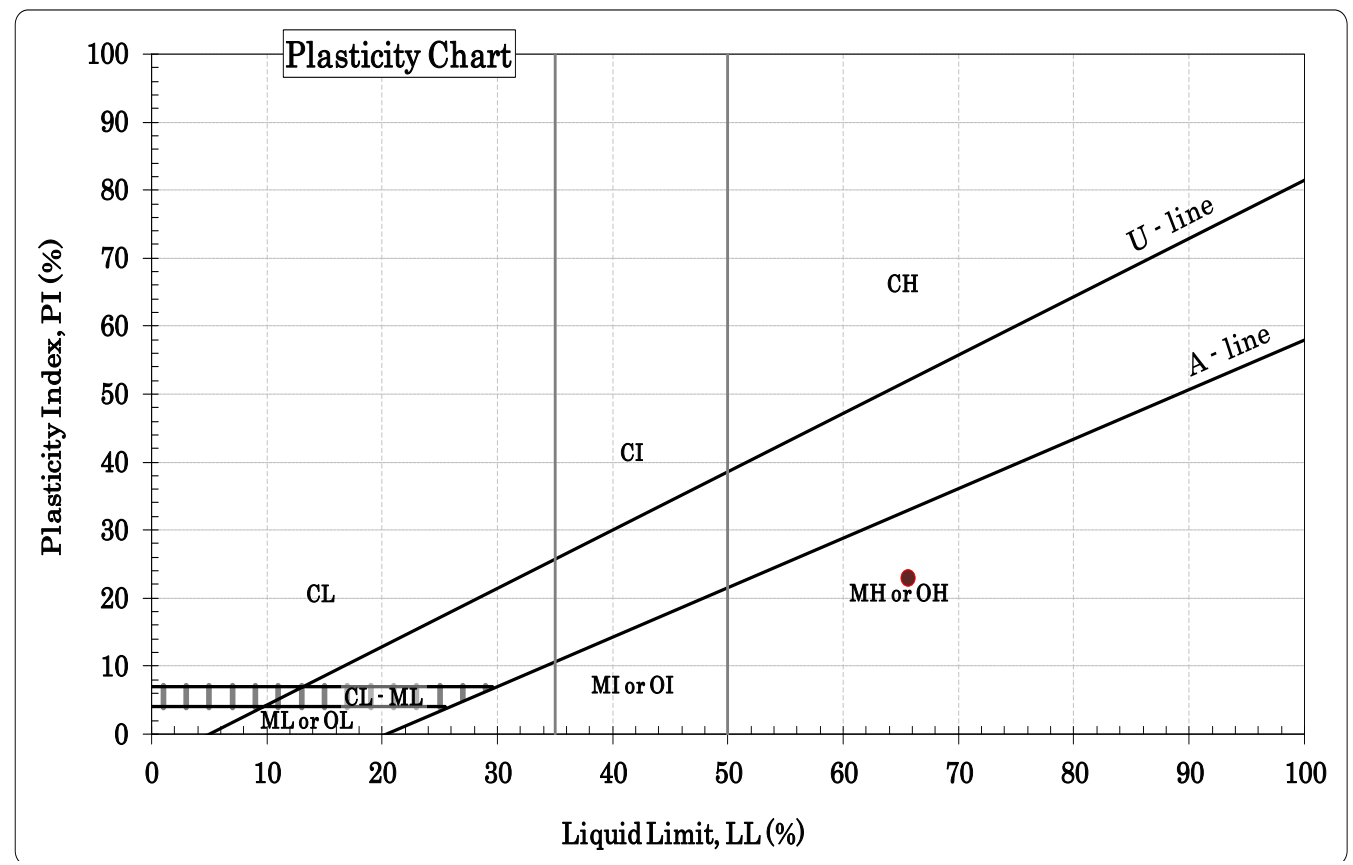

Fig. 7f Plasticity Chart of Sample F

Table 2 Summary of Consistency Limit Tests and Moisture Content

\begin{tabular}{|c|c|c|c|c|}
\hline Sample Location & Natural Moisture Content & \multicolumn{3}{|c|}{ Consistency Limits } \\
\cline { 3 - 5 } & & LL\% & PL\% & PI\% \\
\hline A & 21.4 & 47.1 & 32.3 & 14.8 \\
\hline B & 32.5 & 53.8 & 33.5 & 20.3 \\
\hline C & 33.5 & 59.7 & 36.4 & 23.35 \\
\hline D & 25.7 & 55.9 & 34.2 & 21.75 \\
\hline E & 28.6 & 37.6 & 29.3 & 8.35 \\
\hline F & 35.5 & 65.6 & 42.5 & 23.1 \\
\hline
\end{tabular}


The clay plasticity and subsurface resistivity were synthesized using the following relationship;

The CR-index value $=\left[\left(\mathrm{Wt}_{\text {Clay Plasticity }} * \mathrm{Rt}_{\text {Clay Plasticity }}\right)\right.$

$$
\left.+\left(\mathrm{Wt}_{\text {Surb-Rest }} * \mathrm{Rt}_{\text {Surb-Rest }}\right)\right]
$$

where,

$\mathrm{Wt}=\mathrm{Weight}$

$\mathrm{Rt}=$ Rating

The CR-index corrosivity model map (Fig. 8) shows that the northwestern, northeastern and southern parts of the area are most vulnerable to corrosivity. They are considered to be moderately $(0.4-0.6)$ to strongly corrosive $(0.6-0.8)$, while the upper central of the area and the flanks are considered to be slightly corrosive $(0.2-0.4)$. It was observed that the moderately and strongly corrosive zones correspond to low lands and water logged parts of the study area. The CR-index corrosivity model map was validated using the obtained $\mathrm{pH}$ and conductivity values from the physico-chemical analysis of soil samples (Table 6). The $\mathrm{pH}$ (5.5 - 6.9) and conductivity (007 - 086) values indicated that the samples are slightly acidic and moderately conductive and this obviously validated the generated CR-index corrosivity model. Soil $\mathrm{pH}$ is one of several properties used as a general indicator of soil corrosivity and generally soils that are either highly alkaline or highly acid are likely to be corrosive to metals while soils that have $\mathrm{pH}$ of 5.5 (Table 6) or lower are likely to be highly corrosive to concrete.

Table 3 Weighting of factors for Subsurface Corrosivity

\begin{tabular}{|c|c|}
\hline Parameters & Normalized Weight \\
\hline Subsurface Resistivity & 0.63 \\
\hline Subsurface Plasticity & 0.37 \\
\hline
\end{tabular}

Table 4 Rating of Clay Plasticity

\begin{tabular}{|c|c|}
\hline Clay Plasticity & Rating \\
\hline Plastic Clay (above U-Line) & 0.75 \\
\hline Non-Plastic (between A and U line) & 0.50 \\
\hline Non-Plastic Clay (below A line) & 0.25 \\
\hline
\end{tabular}

Table 5 Rating of Resistivity

\begin{tabular}{|c|c|}
\hline Iso-resistivity (ohm-m) & Rating \\
\hline $0-60$ & 1.0 \\
\hline $60-150$ & 0.8 \\
\hline $150-250$ & 0.6 \\
\hline $250-350$ & 0.4 \\
\hline $350-$ above & 0.2 \\
\hline
\end{tabular}

Table 6 pH and Conductivity Test Results

\begin{tabular}{|c|c|c|}
\hline Sample Location & pH & Conductivity (mhos) \\
\hline A & 6.7 & 033 \\
\hline B & 6.9 & 086 \\
\hline C & 6.5 & 039 \\
\hline D & 6.4 & 029 \\
\hline E & 5.7 & 042 \\
\hline F & 6.2 & 007 \\
\hline
\end{tabular}




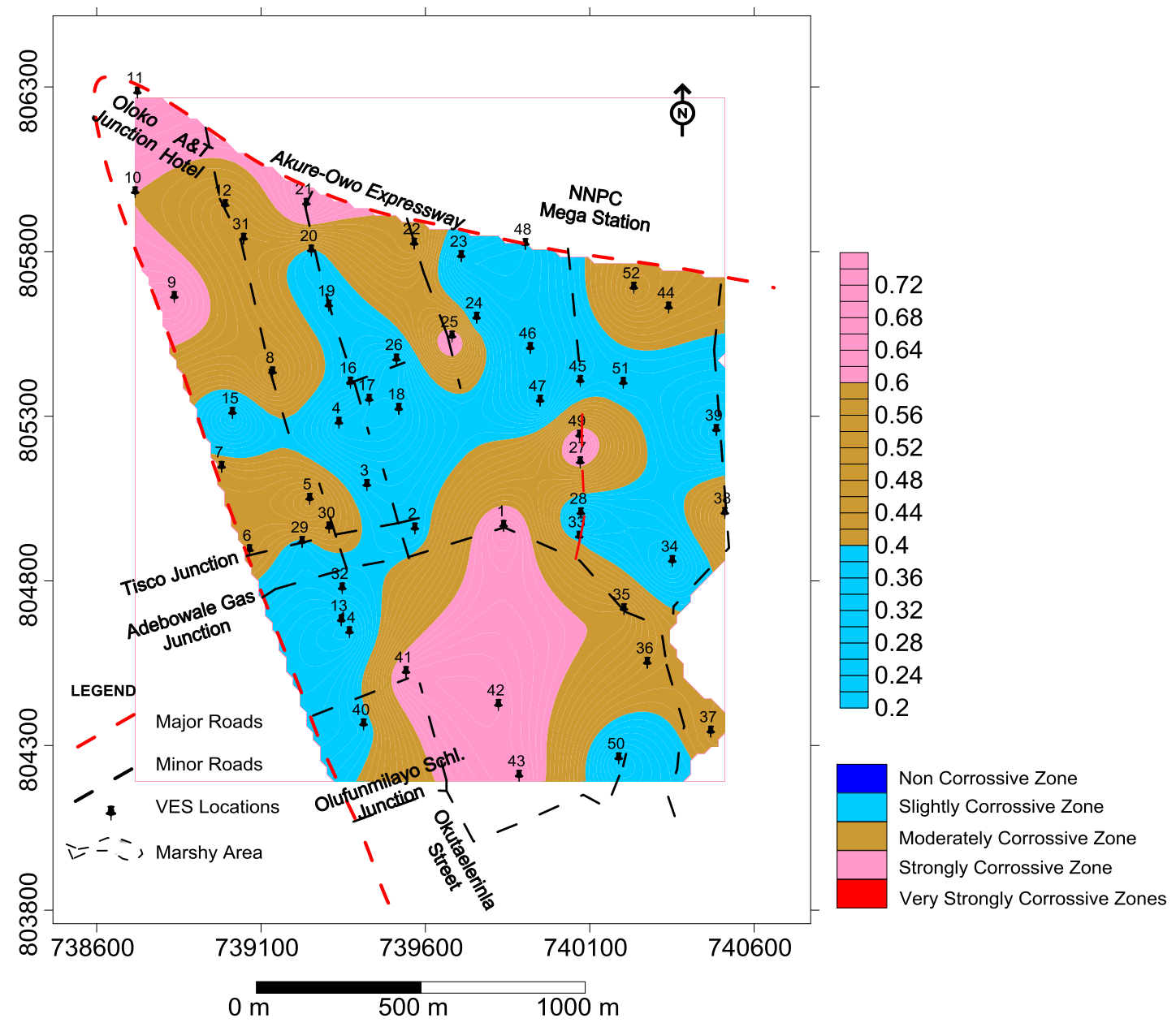

Fig. 8 CR-Index Corrosivity Model Map of the Study Area

\section{Conclusions}

Fifty two vertical electrical sounding (VES) data and six subsurface soil samples were collected at Ondo State Industrial Layout, Akure, Nigeria to determine the subsurface corrosivity. The isoresistivity maps at depth slices of 1 and $2 \mathrm{~m}$ shows that the northeastern, southeastern and the upper central part of the area are non-corrosive (above $350 \mathrm{ohm}-\mathrm{m})$ to slightly corrosive (250 - $350 \mathrm{ohm}$ $\mathrm{m})$, while the lower central, northwestern and southwestern parts of the area are moderately (150 - $250 \mathrm{ohm}-\mathrm{m}$ ) to strongly corrosive (60 - $150 \mathrm{ohm}$ $\mathrm{m})$. Soil sample analysis results shows that all the plasticity index plots were below the A line indicating presence of non-plastic clay. The natural moisture content values vary from 21.4 to $35.5 \%$. The $2 \mathrm{~m}$ depth slice isoresistivity map and clay plasticity factor were synthesized to generate subsurface CR-index corrosivity model map which shows that the northwestern, northeastern and southern parts of the area are moderately $(0.4-0.6)$ to strongly corrosive $(0.6-0.8)$, while the upper central area and the flanks are slightly corrosive. The moderately and strongly corrosive zones correspond to the low elevation and water logged zones of the study area. The corrosivity model map was validated by the $\mathrm{pH}$ and corrosivity data.

\section{Acknowledgements}

The authors wish to acknowledgement the following; Mr J.F. Oladeji and Mr. M.O. Imolore both of the Department of Applied Geology, FUTA for their assistance in carrying out the consistency limit test and the numerous students of the Department of Applied Geophysics FUTA, who assisted during the data acquisition phase of this work.

\section{References}

Abdullahi, N.K., Ugbade, S.F. Abdullahi, M.A. (2016), Engineering Geophysical Study of the Convocation Square, Kaduna State University. Science World Journal Vol 11, No. 3, pp. 1116.

Adeyemo, I.A., Omosuyi, G.O., Ojo, B.T. and Adekunle, A. (2017), Groundwater Potential 
Evaluation in a Typical Basement Complex Environment Using GRT Index - A Case Study of Ipinsa-Okeodu Area, Near Akure, Nigeria. Journal of Geoscience and Environment Protection (GEP), Scientific Research, 5(3): 240 - 251, doi.org/10.4236/gep.2017.53017

Bayowa, O.G. and Olayiwola, N. S. (2015), Electrical Resistivity Investigation for Topsoil Thickness, Competence and Corrosivity Evaluation: A Case Study from Ladoke Akintola University of Technology, Ogbomoso, Nigeria. 2015 2nd International Conference on Geological and Civil Engineering IPCBEE Vol. 80, IACSIT Press, Singapore, doi: 10.7763/ipcbee. 2015. v80. 11

Chachadi A. G. (2005), "Seawater intrusion mapping using modified GALDIT Indicator Model - Case Study in Goa. Jalvigyan Sameeksha, 20: 29 - 45.

Gebremedhin, B. Tesfahunegn, A. and Solomon, G. (2013), Implications of Groundwater Quality to Corrosion Problem and Urban Planning in Mekelle Area, Northern Ethiopia. Momona Ethiopian Journal of Science (MEJS), V5 (1), pp. 51 - 70.

Idornigie, A.I., Olorunfemi, M.O. and Omitogun, A.A. (2006), Electrical Resistivity Determination of Subsurface Layers Soil Competence and Soil Corrosivity at Engineering Site Location in Akungba-Akoko, Southwestern Nigeria. Ife Journal of Science Vol. 8, No. 2, pp. 159 -177.

Koefoed, O. (1979), Geosounding Principles 1. Resistivity Measurements. Elsevier Scientific Publishing, Amsterdam, Netherlands, 275p.

Najjaran, H., Sadiq, R. and Rajani, B. (2004), Modeling pipe deterioration Using Soil Properties - An Application of Fuzzy Logic Expert System. National Research Council Canada A version of this document is published in ACSE International Conference on Pipeline Engineering and Construction, San Diego, CA., August 1-4, 2004, pp. 1-10.

Owate, I.O. Ezi, C.W.I. and Avwiri, G. (2002), Impact of Environmental Conditions on SubSurface Storage Tank (Part 1). International Journal Environmental Management. Vol. 6, No. 2, pp. 79 - 83.

Owoyemi, F.B. (1996), A Geological-Geophysical Investigation of Rain-Induced Erosional Features in Akure Metropolis. Unpublished. M.Tech Thesis, Federal University of Technology: Akure, Nigeria, pp. 11-18.

Oyedele, K.F., Meshida, E. A. and Obidike, C.C. (2012), Assessment of Coastal Soil Corrosivity Using Resistivity Tomography at Lekki. Lagos, Nigeria. International Journal of Science and Advanced Technology. Vol. 2, No. 6, pp. 77 81.
Rahaman, M.A. (1988), Recent advances in the study of the Basement Complex of Nigeria. In: Oluyide, P.O., Mbonu, W.C., Ogezi, A.E., Egbuniwe, I.G., Ajibade, A.C. and Umeji, A.C. (eds.). Precambrian Geology of Nigeria, G.S.N., pp. 11 - 41.

Vander Velpen, B. P. A. (2004), WinRESIST Software Version 1.0. ITC, IT-RSG/GSD, Delft, Netherlands.

Zohdy, A.A.R. 1965. The Auxiliary Point Method of Electrical Sounding Interpretation and its Relationship to Dar Zarrouk Parameters. Geophysics, 30(4): 644 - 660.

\section{Authors}

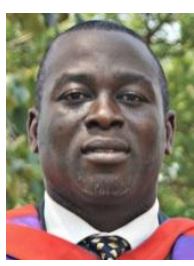

Adeyemo Igbagbo Adedotun is a Lecturer I in the Department of Applied Geophysics, The Federal University of Technology, Akure, Ondo State, Nigeria. He holds degrees of B.Tech (Applied Geology), M.Tech and $\mathrm{PhD}$ (Exploration Geophysics) from the Federal University of Technology, Akure, Nigeria.

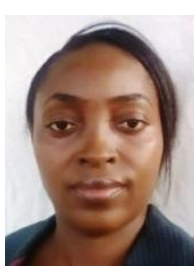

Olumilola Olumide Abiola is a Postgraduate Student in the Deapartment of Applied Geophysics, The Federal University of Technology, Akure, Ondo State, Nigeria. She holds degrees of B.Sc. (Archaeology) University of Ibadan, Oyo State, Nigeria and M.Tech (Exploration Geophysics) from the Federal University of Technology, Akure, Nigeria.

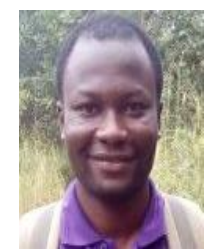

Ibitomi Michael Adewale is a Lecturer in the Department of Mineral and Petroleum Resources Engineering, Kogi State Polythechnic, Lokoja, Kogi State, Nigeria. He holds degrees of B.Tech (Applied Geophysics) and M.Tech (Exploration Geophysics) from the Federal University of Technology, Akure, Nigeria. 